ORIGINAL ARTICLE

\title{
Serum Lipid Profile in Ischemic Heart Disease: A Cross-Sectional Analytical Study
}

\author{
BA Ferduos ${ }^{1}$, N Sultana ${ }^{2}$, S Ahmed ${ }^{3}$, EH Khan ${ }^{4}$, S Sultana ${ }^{1}$, T Parvin 5 \\ ${ }^{1}$ Dept of Biochemistry, Marks Medical College, Dhaka \\ ${ }^{2}$ Dept of Biochemistry, Dhaka Medical College, Dhaka \\ ${ }^{3}$ Dept of Biochemistry, Popular Medical College, Dhaka \\ ${ }^{4}$ Dept of ENT, Holly Family Red Crescent Medical College Hospital, Dhaka \\ ${ }^{5}$ Dept of Cardiology, Bangabandhu Sheikh Mujib Medical University (BSMMU), Dhaka
}

\begin{abstract}
Risk of coronary heart disease and other forms of atherosclerotic vascular diseases, rises with plasma cholesterol concentration and in particular with the rise of ratio of total cholesterol to high density lipoprotein (HDL-C) cholesterol. A much weaker correlation also exists with plasma triglyceride concentration. Extensive large-scale randomized trials have shown that lowering total cholesterol and LDL-C concentrations reduces the risk of cardiovascular events including death, myocardial infarction and stroke and reduces the need for revascularisation.This cross-sectional analytical study was designed to observe association between lipid profile level with chronic ischaemic heart disease and the study was conducted in the Department of Biochemistry, Dhaka Medical College, Dhaka from July 2010 to June 2011. A total of 50 cases were selected purposively according to the selection criteria from the patients admitted in the Department of Cardiology, Dhaka Medical College Hospital with chronic ischaemic heart disease (IHD). Diagnosed IHD patients were taken as cases and 50 age\& sex- matched healthy subjects were taken as controls. Serum TC, TG, LDL-C \& HDL-C were measured in all study subjects. The mean \pm SD of serum TC, TG, HDL-C and LDL-C concentration in cases were $314.54 \pm 73.72 \mathrm{mg} / \mathrm{dl}, 288.04 \pm 60.45 \mathrm{mg} / \mathrm{dl}, 36.02 \pm 4.12 \mathrm{mg} / \mathrm{dl}$, and $178.62 \pm 22.7 \mathrm{mg} / \mathrm{dl}$ respectively and in controls were $174.64 \pm 18.97 \mathrm{mg} / \mathrm{dl}, 119.42 \pm 12.47$ $\mathrm{mg} / \mathrm{dl}, 43.04 \pm 2.58 \mathrm{mg} / \mathrm{dl} \& 126.28 \pm 11.45 \mathrm{mg} / \mathrm{dl}$ respectively. Serum Total Cholesterol, TG \& LDL-C were found to be significantly higher in cases than that of controls. Serum HDL-C was found to be significantly lower in cases than that of controls. The present study reveals that the patients with chronic ischemic heart disease is accociated with significantly higher levels of serum TC, TG and LDL-C whereas HDL-C was found to be lower in IHD patients.
\end{abstract}

Key words: Myocardial infarction, total cholesterol (TC), triacylglycerol, high density lipoprotein (HDL-C) cholesterol, low density lipoprotein (LDL-C) cholesterol.

\section{Introduction}

Atherosclerosis is a progressive inflammatory disorder of the arterial wall that is characterized by focal lipid-rich deposits of atheroma. Atherosclerosis begins early in life. Abnormalities of arterial function have been detected among high-risk children and adolescents, such as cigarette smokers and those with familial hyperlipidemia or hypertension 1. In the recent past there has been an addition of

several molecular markers to the well established risk factors of smoking, family history, hypertension, diabetes and high levels of LDL cholesterol ${ }^{2}$. In current strategies of coronary risk assessment, lipid testing in the blood routinely recommended 3 . Because of critical importance of LDL-C in atherogenesis, LDL-C is the focus for the determination of the risk of coronary disease 4 .

Bangladesh J Med Biochem 2014; 7(1): 14-16 
Serum Lipid Profile in Ischemic Heart Disease

\section{Materials and Methods}

The study was carried out in the Department of Biochemistry, Dhaka Medical College, Dhaka during the period of July 2010 to June 2011. The patients were taken from the Department of Cardiology, Dhaka Medical College Hospital. Fifty diagnosed chronic IHD patients of both sexes with age range of 30-65 years were taken as cases and 50 age and sex matched healthy volunteers were taken as controls. Cases were the diagnosed (positive ECG findings) chronic IHD patients of both sexes admitted in the hospital during the study period. Of the cases 31 were males and 19 were females and in controls 28 were males and 22 were females. Fasting lipid profile was measured in all study subjects using standard laboratory method. All statistical analyses were done by SPSS, version 17.0. Results were expressed as mean \pm SD. Student's ' $t$ ' test was done to see the difference between groups and $\mathrm{P}<0.05$ was considered as significant.

\section{Results}

Sex distribution of the study subjects are presented in Table-I. Cases included 31 males and 19 females of chronic IHD patients of age range $30-65$ years. In healthy controls 28 were males and 22 were females with an age range 30 65 years.

Table-I: Sex distribution of the study subjects

\begin{tabular}{lcl} 
Sex & $\begin{array}{l}\text { Cases } \\
(\mathrm{n}=50)\end{array}$ & $\begin{array}{l}\text { Controls } \\
(\mathrm{n}=50)\end{array}$ \\
\hline Male & $31(62.0)$ & $28(56.0)$ \\
Female & $19(38.0)$ & $22(44.0)$ \\
\hline
\end{tabular}

Figures in parentheses indicate percentages

Table-II shows the lipid profile in different groups. Mean \pm SD of serum TC, TG, HDL-C and LDL-C in cases were $314.54 \pm 73.72 \mathrm{mg} / \mathrm{dl}, 288.04 \pm 60.45$ $\mathrm{mg} / \mathrm{dl}, 36.02 \pm 4.12 \mathrm{mg} / \mathrm{dl}$ and $178.62 \pm 22.7 \mathrm{mg} / \mathrm{dl}$ respectively and in controls were $174.64 \pm 18.97$ $\mathrm{mg} / \mathrm{dl}, 119.42 \pm 12.47 \mathrm{mg} / \mathrm{dl}, 43.04 \pm 2.58 \mathrm{mg} / \mathrm{dl}$ and $126.28 \pm 11.45 \mathrm{mg} / \mathrm{dl}$ respectively. It showed that mean $( \pm$ SD) of TC, TG, LDL-C were significantly higher in cases than that of controls and mean $( \pm \mathrm{SD})$ HDL-C was significantly lower in cases than that of controls.
Table-II: Lipid profile of the study subjects

\begin{tabular}{lllll}
\hline Parameters & $\begin{array}{c}\text { Cases } \\
(\mathrm{n}=50)\end{array}$ & $\begin{array}{l}\text { Controls } \\
(\mathrm{n}=50)\end{array}$ & t value & p value \\
$\mathrm{TC}(\mathrm{mg} / \mathrm{dl})$ & & & \\
\hline $\begin{array}{l}\text { Mean } \pm \mathrm{SD} \\
\text { Range }\end{array}$ & $314.54 \pm 73.72$ & $174.64 \pm 18.97$ & 12.995 & $0.0001^{*}$ \\
& $160.00-440.00$ & $130.00-210.00$ & & \\
$\mathrm{TG}(\mathrm{mg} / \mathrm{dl})$ & & & & \\
\hline Mean $\pm \mathrm{SD}$ & $288.04 \pm 60.45$ & $119.42 \pm 12.47$ & 19.316 & $0.0001^{*}$ \\
Range & $171.00-370.00$ & $90.00-150.00$ & & \\
& & & & \\
LDL $\mathbf{c}(\mathrm{mg} / \mathrm{dl})$ & & & & \\
\hline Mean $\pm \mathrm{SD}$ & $178.62 \pm 22.70$ & $126.28 \pm 11.45$ & 14.557 & $0.0001^{*}$ \\
Range & $150.00-230.00$ & $104.00-150.00$ & & \\
& & & & \\
HDL $\mathbf{c}(\mathrm{mg} / \mathrm{dl})$ & & & & \\
\hline Mean $\pm \mathrm{SD}$ & $36.02 \pm 4.12$ & $43.04 \pm 2.58$ & 10.207 & $0.0001^{*}$ \\
Range & $20.00-40.00$ & $40.00-48.00$ & & \\
\hline
\end{tabular}

$p$ value reached from unpaired student's ' $t$ ' test.

* indicates significance.

\section{Discussion}

In atherosclerosis, fatty streaks tend to occur at sites of altered arterial shear stress such as bifurcations and are associated with abnormal endothelial function. They develop when inflammatory cells, predominantly monocytes, bind to receptors expressed by endothelial cells, migrate into the intima, take up oxidized lowdensity lipoprotein (LDL) from the plasma and become lipid laden foam cells or macrophages. Extra-cellular lipid pools appear in the intimal space when these foam cells die and release their contents. Smooth muscle cells then migrate from the media of the arterial wall into the intima, in response to cytokines and growth factors produced by the activated macrophages, change from a contractile to a repair phenotype in an attempt to stabilise the atherosclerotic lesion. If they are successful, the lipid core will be covered by smooth muscle cells and matrix, producing a stable atherosclerotic plaque that will remain asymptomatic until it becomes large enough to obstruct arterial flow1. Jelovesk (1997) has categorically proposed hypercholesterolemia and hyperlipidemia as risk factors for vascular disease ${ }^{5}$. The present study has revealed the 
mean \pm SD of serum TC, TG, HDL-C and LDL$\mathrm{C}$ in cases were $314.54 \pm 73.72 \mathrm{mg} / \mathrm{dl}$, $288.04 \pm 60.45 \mathrm{mg} / \mathrm{dl}, 36.02 \pm 4.12 \mathrm{mg} / \mathrm{dl}$ and $178.62 \pm 22.7 \mathrm{mg} / \mathrm{dl}$ respectively and that in controls were $174.64 \pm 18.97 \mathrm{mg} / \mathrm{dl}, 119.42 \pm 12.47$ $\mathrm{mg} / \mathrm{dl}, \quad 43.04 \pm 2.58 \mathrm{mg} / \mathrm{dl}$ and $126.28 \pm 11.45$ $\mathrm{mg} / \mathrm{dl}$ respectively. In our study TC, TG and LDL-C values were found to be significantly higher and HDL-C value was found to be significantly lower in cases compared to that of controls. These findings are in agreement with that of other studies6-8. Growing evidences support that atherosclerosis is an inflammatory process initiated by vascular injury, oxidized LDL, reactive oxygen species, diabetes mellitus and infections. Several plasma markers of inflammation have been evaluated as potential tools for the prediction of the coronary events9. To predict the patients at risk of progression to an acute vascular event there has been an addition of several molecular markers in recent past to well established risk factors like smoking, family history, life style, hypertension, diabetes \& high level of LDL cholesterol ${ }^{3}$. Cholesterol screening has been used as a tool to identify individuals who are at increased risk of developing future coronary events 10 . A number of predisposing factors affect the development of ischemic heart disease (IHD) and to date more than 246 risk factors have been identified including dyslipidemia, a major risk factor for development of atherosclerosis 11 . This study suggests that even in modern era, lipid profile still is a promising predictive biomarker of coronary risk assessment.

\section{References}

1. Newby DE, Grubb NR, Bradbury A. Cardio Vascular Disease. NR College, BR Walker, SH Ralston (eds). Davidson's Principles \& Practice of Medicine; 2010, 21st edition, Churchill Livingstone Elsevier Limited New Delhi, pp. 577-579 .

2. Brown DA, Breit SN. CRP and Vascular Risk. Sydpath; (06/06/2002); Available from: http://www.sydpath.stvincent.com.au/ tests/ CRPRisk. htm
3. Ridker PM, Glynn RJ, Hennekens CH. C-Reactive Protein Adds to the Predictive Value of Total and HDL Cholesterol in Determining Risk of First Myocardial Infarction. Circulation 1998; 97: 2007 2011.

4. Ridker PM, Rifai N, Rose L, Buring JE, Cook NR. Comparison of C-Reactive Protein and Low Density Lipoprotein Cholesterol Levels in the Prediction of First Cardiovascular Events. N Eng J Med 2002; 347: 1557-1565.

5. Jelovesek FR. Cholesterol and Lipid Disorders. Women's Diagnostic Cyber; 1997; Available from: http://www.wedxcyber.com/ngen 15.htm, 6 July 2004.

6. Ridker PM, Cushman M, Stampfer MJ, Tracy RP, Hennekens CH. Inflammation, Aspirin and the Risk of Cardiovascular Disease in Apparently Healthy Men. N Eng J Med 1997; 336: 973-979.

7. Ridker PM, Glynn RJ, Hennekens CH. C-Reactive Protein Adds to the Predictive Value of Total and HDL Cholesterol in Determining Risk of First Myocardial Infarction. Circulation 1998; 97: 20072011.

8. Ridker PM, Glynn RJ, Hennekens CH, Buring JE. CRP \& Other Marker of Inflammation in the Prediction of Cardiovascular Disease in Women. N Eng J Med 2000; 342: 836-843.

9. Ross R. Atherosclerosis-An Inflammatory Disease. New Eng J Med 1999; 340: 115-126.

10. Rifai N, Ridker PM. Proposed Cardiovascular Risk Assessment Algorithm Using High Sensitivity CReactive Protein And Lipid Screening. Clin Chem 2001; 47: 28-30.

11. Grundy SM, D Agostino RB, Mosca L, Burke GL, Wilson PWF, Rader DJ, Cleenman JI, Roccella EJ, Cutler JA, Friedman LM. Cardiovascular Risk Assessment Based on US Cohort Studies. Circulation 1999; 104: 491-496. 